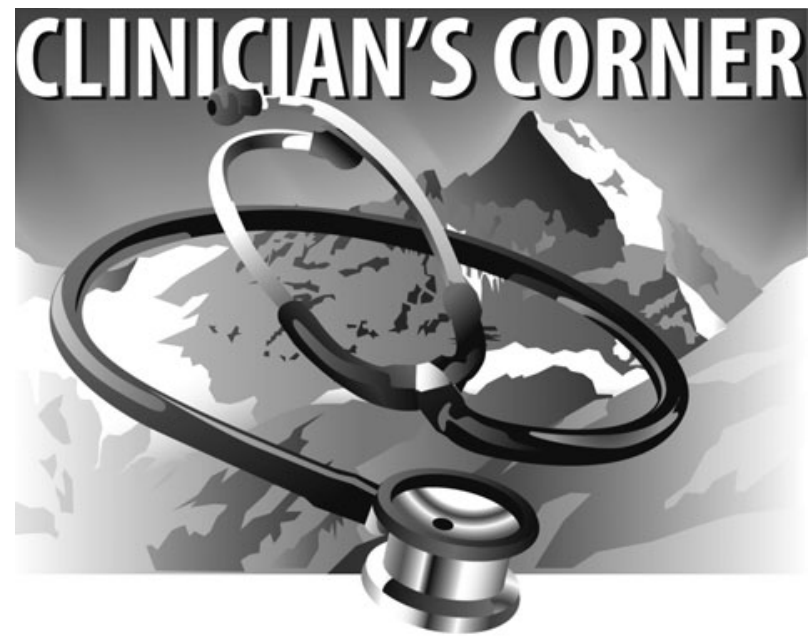

\title{
Chronic Mountain Sickness: Clinical Aspects, Etiology, Management, and Treatment
}

\author{
Francisco C. Villafuerte and Noemí Corante
}

\begin{abstract}
Villafuerte, Francisco C., and Noemí Corante. Chronic mountain sickness: clinical aspects, etiology, management, and treatment. High Alt Med Biol. 17:61-69, 2016.-Millions of people worldwide live at a high altitude, and a significant number are at risk of developing Chronic Mountain Sickness (CMS), a progressive incapacitating syndrome caused by lifelong exposure to hypoxia. CMS is characterized by severe symptomatic excessive erythrocytosis (EE; $\mathrm{Hb} \geq 19 \mathrm{~g} / \mathrm{dL}$ for women and $\mathrm{Hb} \geq 21 \mathrm{~g} / \mathrm{dL}$ for men) and accentuated hypoxemia, which are frequently associated with pulmonary hypertension. In advanced cases, the condition may evolve to cor pulmonale and congestive heart failure. Current knowledge indicates a genetic predisposition to develop CMS. However, there are important risk factors and comorbidities that may trigger and aggravate the condition. Thus, appropriate medical information on CMS is necessary to provide adequate diagnosis and healthcare to high-altitude inhabitants. After reviewing basic clinical aspects of CMS, including its definition, diagnosis, and common clinical findings, we discuss aspects of its etiology, and address its epidemiology, risk factors, and treatment.
\end{abstract}

Key Words: chronic hypoxia; chronic mountain sickness; excessive erythrocytosis; high altitude

\section{Introduction}

$\mathbf{C}$ HRONIC MOUNTAIN SICKNESS (CMS) or Monge's disease is a highly prevalent progressive incapacitating syndrome in most high-altitude regions around the world. More than 140 million people live above $2500 \mathrm{~m}$ worldwide, and on average, $5 \%-10 \%$ are at risk of developing CMS (LeonVelarde et al., 2005). Also, we can expect an increase of migration to altitude locations due to developing economic activities and population growth. Thus, there is the need for appropriate medical information of this condition to provide adequate diagnosis and healthcare to high-altitude inhabitants at risk of developing this syndrome.

The purpose of this review is to address clinical aspects of the condition, including its definition, diagnosis, and common clinical findings; discuss aspects of its etiology; and review its current epidemiology, risk factors, and treatment strategies.

Laboratorio de Fisiología Comparada, Departamento de Ciencias Biológicas y Fisiológicas, Facultad de Ciencias y Filosofía, Universidad Peruana Cayetano Heredia, Lima, Perú.

(C) Francisco C. Villafuerte and Noemí Corante, 2016; Published by Mary Ann Liebert, Inc. This Open Access article is distributed under the terms of the Creative Commons Attribution Noncommercial License (http://creativecommons.org/licenses/by-nc/4.0/), which permits any noncommercial use, distribution, and reproduction in any medium, provided the original author(s) and the source are credited. 


\section{What Is CMS and in Whom Does it Develop?}

According to the international consensus on chronic and sub-acute high-altitude diseases (Leon-Velarde et al., 2005), CMS is defined as a clinical syndrome that occurs in natives or lifelong altitude residents $(>2500 \mathrm{~m})$, and it is characterized by excessive erythrocytosis (EE) and severe hypoxemia (Table 1). Frequently, it is associated with moderate or severe pulmonary hypertension that may evolve to cor pulmonale and lead to congestive heart failure. The clinical picture of CMS gradually disappears upon descent to low altitudes and reappears after returning to high altitude.

$\mathrm{EE}$ is defined as two standard deviations above the mean hemoglobin $(\mathrm{Hb})$ concentration value of the population at the altitude of residence (Monge et al., 1989). By consensus, the cut-off values for $\mathrm{EE}$ are $\mathrm{Hb} \geq 19 \mathrm{~g} / \mathrm{dL}$ for women and $\mathrm{Hb}$ $\geq 21 \mathrm{~g} / \mathrm{dL}$ for men based on epidemiological studies in the central Andes of Perú (Cerro de Pasco, 4340 m) (LeonVelarde et al., 2005).

There is the need, however, of further epidemiological studies to appropriately determine altitude-specific $\mathrm{Hb}$ distribution and prevalence of CMS.

\section{Epidemiology}

Prevalence of CMS has shown considerable variability through the different high-altitude populations worldwide. At a similar altitude and using the same diagnostic criteria, this variability could be attributed mainly to differences in ethnicity. Various ethnic groups have occupied the highlands at distant time-points in human history and, therefore, have had different periods of adaptation to chronic hypoxia. Those with a longer time at high altitude are more likely to be better adapted. In this sense, it is believed that native Tibetans and Ethiopians are the most adapted ethnic groups when compared with Andeans and Han immigrants (Moore, 2001). This adaptation is reflected essentially in a lower $\mathrm{Hb}$ concentration, and therefore in a lower prevalence of EE and CMS. Accordingly, the lowest values are found in Tibetans from Qinghai, China with a CMS prevalence of $1.21 \%$; whereas in Han immigrants, it was $5.6 \%$ in the same city (Wu et al., 1998). In the Andes, the prevalence of CMS has been evaluated mainly in three locations: Puno and Cerro de Pasco in Perú; and in La Paz, Bolivia. In Puno (3800 m) the prevalence was 6\% (De Ferrari et al., 2014), and in La Paz $(3600 \mathrm{~m})$ it was $5.2 \%$ (Spielvogel et al., 1981). The highest values were reported in Andeans from Cerro de Pasco, where the prevalence was $15.4 \%$ in men between 30 and 39 years, and reached $33 \%$ by the sixth decade of age (Monge et al., 1989). As altitude increases, an increment in prevalence values can also be observed. In the Tibetan plateau, at 2261$2980 \mathrm{~m}$, CMS was found in $1.05 \%$ of the population; at 3128$3980 \mathrm{~m}$, in $3.75 \%$; and at 4000-5226 m, in $11.83 \%$ (Wu et al., 1998). Also, a study in Himachal Pradesh, India, between 2350 and $3000 \mathrm{~m}$ reported no cases of CMS; whereas between 3000 and $4150 \mathrm{~m}$, the prevalence was 13.3\% (Sahota and Panwar, 2013).

\section{Diagnosis}

CMS (primary CMS) is diagnosed based on the absence of any condition that may aggravate hypoxemia and lead to the development of EE. Cases of chronic pulmonary disease (such as pulmonary emphysema, chronic bronchitis, bronchiectasis, cystic fibrosis, lung cancer), or other underlying chronic medical conditions that worsen hypoxemia are consistent with development of secondary CMS. Normal respiratory function should be confirmed by lung function tests.

Once causes for secondary CMS are discarded, diagnosis of primary CMS is based on the presence of clinical symptoms, including headache, dizziness, breathlessness and/or palpitations, sleep disturbances, fatigue, localized cyanosis, burning in the palms of hands and soles of feet, dilatation of veins, muscle and joint pain, loss of appetite, lack of mental concentration, and alterations of memory. Clinical signs include EE, severe hypoxemia, pulmonary hypertension (not mandatory, $\mathrm{mPAP}>30 \mathrm{mmHg}$ or PASP $>50 \mathrm{mmHg}$ measured

Table 1. Physiological Characteristics of Healthy and CMS Andean Highlanders (4340m)

\begin{tabular}{|c|c|c|c|c|}
\hline & Healthy highlanders (n) & CMS Patients (n) & $\mathrm{p}$ & Reference \\
\hline $\mathrm{Hb}, \mathrm{g} / \mathrm{dL}$ & $17.7 \pm 0.15$ & $22.7 \pm 0.25(42)$ & $<0.001$ & Villafuerte et al. (2014) \\
\hline Hct, \% & $52.9 \pm 0.44(44)$ & $68.0 \pm 0.80(42)$ & $<0.001$ & Villafuerte et al. (2014) \\
\hline $\mathrm{SpO}_{2}, \%$ & $88.2 \pm 0.62(44)$ & $84.0 \pm 0.60(42)$ & $<0.001$ & Villafuerte et al. (2014) \\
\hline CMS score & $2.7 \pm 0.38$ & $7.4 \pm 0.60$ & $<0.001$ & Villafuerte et al. (2014) \\
\hline Blood volume, $\mathrm{mL} / \mathrm{kg}$ & $83.6 \pm 4.00(11)$ & $106.5 \pm 8.30(11)$ & $<0.050$ & Claydon et al. (2004) \\
\hline $\mathrm{PaO}_{2}, \mathrm{mmHg}$ & $49.0 \pm 0.52(15)$ & $42.0 \pm 0.54(55)$ & $<0.001$ & Maignan et al. (2009) \\
\hline $\mathrm{PaCO}_{2}, \mathrm{mmHg}$ & $24.0 \pm 0.26(15)$ & $29.0 \pm 0.40(55)$ & $<0.001$ & Maignan et al. (2009) \\
\hline Bicarbonate, $\mathrm{mmol} / \mathrm{L}$ & $18.4 \pm 0.28(15)$ & $20.3 \pm 0.26(55)$ & $<0.001$ & Maignan et al. (2009) \\
\hline Arterial pH & $7.50 \pm 0.01(15)$ & $7.47 \pm 0.00$ & $<0.001$ & Maignan et al. (2009) \\
\hline Serum iron, $\mu \mathrm{g} / \mathrm{dL}$ & $110.3 \pm 7.82(44)$ & $124.6 \pm 13.5(42)$ & 0.346 & Villafuerte et al. (2014) \\
\hline Serum ferritin, $\mathrm{ng} / \mathrm{mL}$ & $136.2 \pm 14.3(44)$ & $183.2 \pm 22.4(42)$ & 0.074 & Villafuerte et al. (2014) \\
\hline Transferrin saturation, \% & $32.8 \pm 2.38(44)$ & $32.8 \pm 3.10(42)$ & 0.987 & Villafuerte et al. (2014) \\
\hline $\mathrm{SBP}, \mathrm{mmHg}$ & $104.0 \pm 2.53(10)$ & $121.0 \pm 2.27(28)$ & $<0.001$ & Richalet et al. (2005) \\
\hline $\mathrm{DBP}, \mathrm{mmHg}$ & $62.0 \pm 2.53(10)$ & $73.0 \pm 2.08(28)$ & 0.003 & Richalet et al. (2005) \\
\hline $\mathrm{TR}, \mathrm{mmHg}$ (Echo) & $25.0 \pm 1.03(15)$ & $34.0 \pm 1.54(42)$ & 0.002 & Maignan et al. (2009) \\
\hline mPAP, mmHg (Cath.) ${ }^{\mathrm{a}}$ & $23.0 \pm 1.47(12)$ & $47.0 \pm 5.60(10)$ & $<0.001$ & Peñaloza and Arias-Stella (2007) \\
\hline
\end{tabular}

Values are expressed as means \pm SE.

${ }^{\mathrm{a}}$ Measured at Morococha, Peru, $4500 \mathrm{~m}$ by catheterization.

CMS, chronic mountain sickness; Hb, hemoglobin concentration; Hct, hematocrit; $\mathrm{SpO}_{2}$, pulse $\mathrm{O}_{2}$ saturation; SBP, systolic blood pressure; DBP, diastolic blood pressure; $\mathrm{PaO}_{2}$, arterial $\mathrm{O}_{2}$ pressure; $\mathrm{PaCO}_{2}$, arterial $\mathrm{CO}_{2}$ pressure; TR, tricuspid regurgitation gradient pressure; mPAP, mean pulmonary artery pressure. 
at the altitude of residence), and signs of mild or moderate congestive heart failure (not mandatory). Of note, given the altitude dependence of $\mathrm{SpO}_{2}$ and the significant variability of $\mathrm{Hb}$ concentration with $\mathrm{SpO}_{2}$ (up to $15 \%$ in the $\mathrm{SpO}_{2}$ range of $70 \%-85 \%)$, it is difficult to adopt a single threshold value for defining accentuated or severe hypoxemia. Nevertheless, some cut-off values have been proposed for different regions and altitudes. Epidemiological studies in Peru at $4340 \mathrm{~m}$ proposed a threshold $\mathrm{SpO}_{2}<83 \%$ (Monge et al., 1992) or $<81.5 \%$ (Leon-Velarde et al., 1994); whereas for the Qinghai-Tibetan plateau, the Chinese High Altitude Medical Association proposed a threshold of $<85 \%$ (CHAMA, 1996). The severity of CMS is assessed using the Qinghai Score based on $\mathrm{Hb}$ concentration (presence or absence of $\mathrm{EE}$ ) and on the presence and extent of a group of signs and symptoms agreed by international consensus as shown in Table 2 (Leon-Velarde et al., 2005). According to the sum of individual scores of each sign and symptom, the presence and severity of CMS is assessed as shown in Table 3.

\section{Common Clinical Findings and Co-Morbidities in CMS}

Excessive erythocytosis is accompanied by hypervolemia and generalized dilatation of blood vessels. Patients appear deeply cyanotic as a result of EE and hypoxemia. Char-

Table 2. The Qinghai Score for CMS

\begin{tabular}{|c|c|}
\hline Signs or symptoms & Score \\
\hline $\begin{array}{l}\text { Breathlessness and/or } \\
\text { palpitations }\end{array}$ & $\begin{array}{l}0 \text { No breathlessness/palpitations } \\
1 \text { Mild breathlessness/palpitations } \\
2 \text { Moderate breathlessness/ } \\
\text { palpitations } \\
3 \text { Severe breathlessness/palpitations }\end{array}$ \\
\hline Sleep disturbance & $\begin{array}{l}0 \text { Slept as well as usual } \\
1 \text { Did not sleep as well as usual } \\
2 \text { Woke up many times, poor } \\
\text { night's sleep } \\
3 \text { Could not sleep at all }\end{array}$ \\
\hline Cyanosis & $\begin{array}{l}0 \text { No cyanosis } \\
1 \text { Mild cyanosis } \\
2 \text { Moderate cyanosis } \\
3 \text { Severe cyanosis }\end{array}$ \\
\hline Dilatation of veins & $\begin{array}{l}0 \text { No dilatation of veins } \\
1 \text { Mild dilatation of veins } \\
2 \text { Moderate dilatation of veins } \\
3 \text { Severe dilatation of veins }\end{array}$ \\
\hline Paresthesia & $\begin{array}{l}0 \text { No paresthesia } \\
1 \text { Mild paresthesia } \\
2 \text { Moderate paresthesia } \\
3 \text { Severe paresthesia }\end{array}$ \\
\hline Headache & $\begin{array}{l}0 \text { No headache } \\
1 \text { Mild headache symptoms } \\
2 \text { Moderate headache } \\
3 \text { Severe headache, incapacitating }\end{array}$ \\
\hline Tinnitus & $\begin{array}{l}0 \text { No tinnitus } \\
1 \text { Mild tinnitus } \\
2 \text { Moderate tinnitus } \\
3 \text { Severe tinnitus }\end{array}$ \\
\hline $\begin{array}{l}\text { Hemoglobin } \\
\text { concentration }\end{array}$ & $\begin{array}{l}\text { Men: } \\
<21 \mathrm{~g} / \mathrm{dL} ; \text { score }=0 \\
\geq 21 \mathrm{~g} / \mathrm{dL} ; \text { score }=3 \\
\text { Women: } \\
<19 \mathrm{~g} / \mathrm{dL} ; \text { score }=0 \\
\geq 19 \mathrm{~g} / \mathrm{dL} ; \text { score }=3\end{array}$ \\
\hline
\end{tabular}

Table 3. Assessment of CMS Severity with Total Qinghai Score

\begin{tabular}{ll}
\hline Total score & \multicolumn{1}{c}{ CMS } \\
\hline $0-5$ & Absent \\
$6-10$ & Mild \\
$11-14$ & Moderate \\
$>15$ & Severe \\
\hline
\end{tabular}

acteristic clubbing of fingers and toes is commonly observed. Mucous membranes of the mouth and throat show deep cyanosis (Fig. 1). The eyes appear watery and the conjunctivae are markedly hyperemic, with prominently distended capillary patterns. Retinal vessels are also dilated and congested (Hurtado, 1942; Monge, 1943; Winslow and Monge, 1987; Claydon et al., 2004).

Patients are likely to complain of decreased exercise tolerance and bone and joint pain, although there is controversy whether aerobic capacity is decreased in these subjects (Winslow and Monge, 1987; Groepenhoff et al., 2012). There is also a characteristic complaint of dyspnea, insomnia, dizziness, headache, paresthesias, and mental confusion (Monge, 1943; Winslow and Monge, 1987; Leon-Velarde et al., 2014). Moderate hemoptysis and epistaxis episodes are also common (Hurtado, 1942; Monge, 1942, 1943). Occasionally, subjects may have symptomatic diastolic hypertension, and sometimes, systolic hypertension (Winslow and Monge, 1987).

Radiographic examination reveals increased cardiac size, mainly due to right-ventricular hypertrophy (Peñaloza et al., 1971). The main pulmonary artery is prominent in all patients, and pulmonary vascular markings are accentuated in the central and peripheral regions of the lung fields (Peñaloza et al., 1971; Peñaloza and Arias-Stella, 2007). The right atrium frequently appears enlarged. Pulmonary vasculature is congested, and left-ventricular hypertrophy occurs in advanced cases. Electrocardiogram often shows a p-pulmonale pattern, right QRS deviation, rS pattern in the right precordial leads, complexes of RS or rS type in the left precordial leads, and negative $\mathrm{T}$ waves in the right precordial leads (Peñaloza and Arias-Stella, 2007).

Autopsy of CMS patients shows generalized brain and visceral congestion. Pulmonary arterial branches show marked muscularization exceeding normal values for the altitude of residence. Also, intimal thickening in small- and medium-sized pulmonary branches is observed as well as the presence of multiple pulmonary arterial thrombi (AriasStella, 1971).

Functionally, in addition to increased pulmonary arteriolar muscularization, an augmented degree of arteriolar vasoconstriction appears to contribute to the accentuated pulmonary hypertension in CMS patients, resulting in the characteristic cardiac enlargement (Peñaloza and Arias-Stella, 2007). EE and systemic diastolic hypertension might also contribute to increased cardiac size. Chronic cor pulmonale and congestive signs of heart failure are observed in severe or advanced CMS cases (Peñaloza et al., 1971). Common death causes include cardiac insufficiency and strokes.

At present, there are no data on mortality by CMS. However, a considerable burden of the disease has been calculated for Chinese immigrants at Tibet (Pei et al., 2012), and it can be increased by co-morbidities associated with the disease, such as metabolic syndrome and vascular dysfunction (Rimoldi 

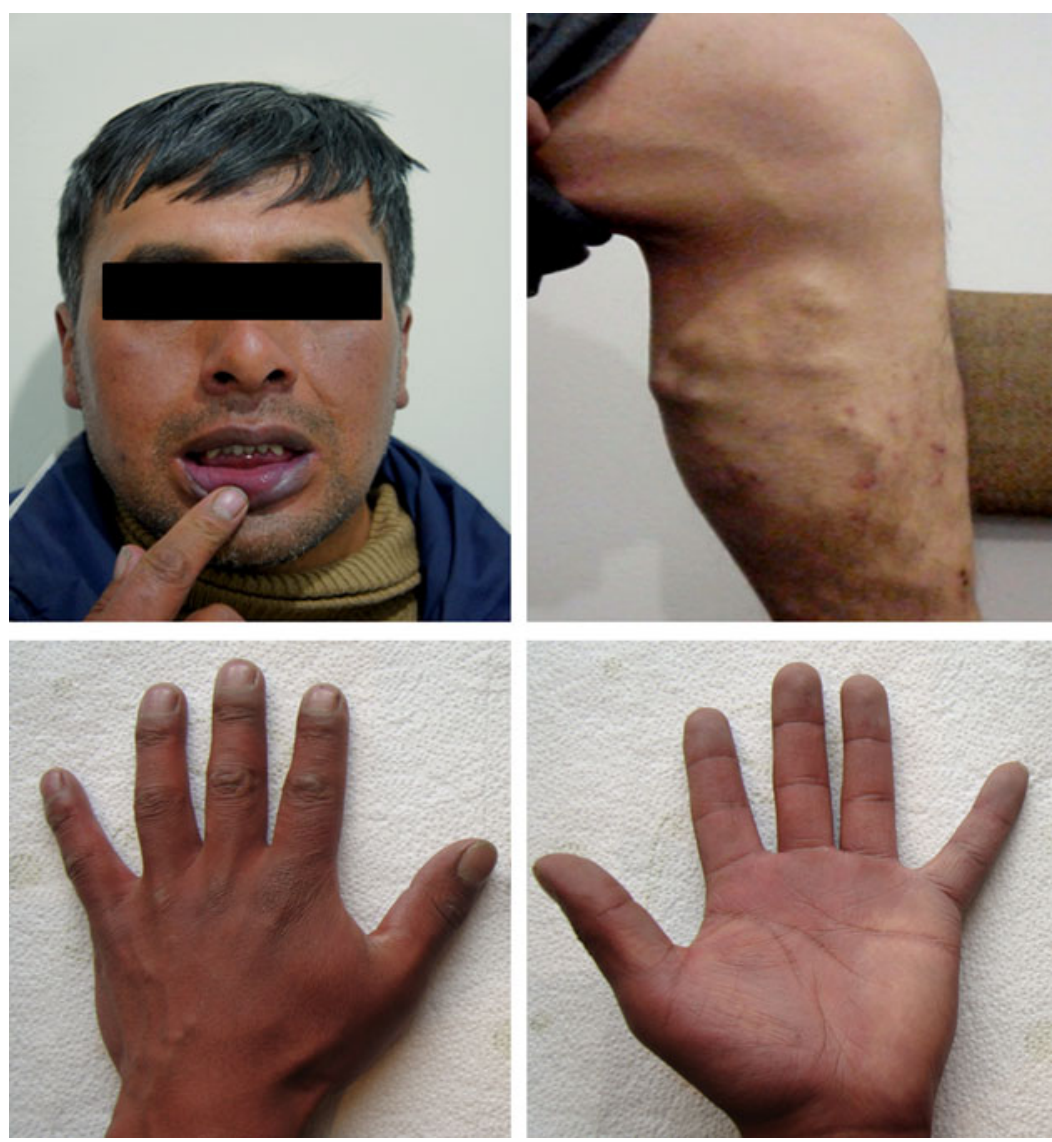

FIG. 1. Typical CMS patient. Note the deep purplish color of lips and gums as a consequence of $\mathrm{EE}_{\text {and }}$ low $\mathrm{SpO} \mathrm{O}_{2}$ Vein dilatation is particularly evident in the lower limbs, and characteristic clubbing of fingers and marked cyanosis are evident in nail beds and palms of the hands. CMS, chronic mountain sickness; EE, excessive erythrocytosis.

et al., 2012; De Ferrari et al., 2014). Elevated serum triglycerides, reduced HDL levels, systolic or diastolic hypertension, and insulin resistance might also be independently associated with the condition (Leon-Velarde and Arregui, 1994; Jefferson et al., 2002; Okumiya et al., 2010, 2011; Sherpa et al., 2011; Gonzales and Tapia, 2013; De Ferrari et al., 2014). Also, elevated $\mathrm{Hb}$ concentration in CMS patients increases the production of pro-inflammatory markers and is associated with the presence of oxidative-nitrosative stress (Bailey et al., 2013). Inflammatory and oxidative damage to the vascular endothelium contributes to the development of atherosclerosis and the consequent increment in the risk of cardiovascular events (Stocker and Keaney, 2004) such as vascular occlusion, myocardial ischemia, and stroke.

\section{What Causes CMS?}

Chronic hypoxic exposure is widely accepted as the underlying cause of CMS. However, its fundamental pathophysiological mechanism is still not completely clear. The loss of ventilatory acclimatization to altitude hypoxia leading to central hypoventilation has been proposed as the principal mechanism explaining accentuated hypoxemia and the subsequent excessive erythropoietic response (Leon-Velarde and Richalet, 2006; Fig. 2). The relationship between $\mathrm{SpO}_{2}, \mathrm{Hb}$, and the main erythropoietic hormone, erythropoietin (Epo) is, however, less clear. Contrary to what can be expected, there is no correlation between morning Epo and $\mathrm{SpO}_{2}$ or $\mathrm{Hb}$ in CMS patients. This lack of correlation is the result of the existence of two sub-groups of CMS patients: those with normal Epo values similar to those of healthy highlanders, and those with high serum Epo. Recently, this lack of correlation has been concealed by considering the concept of Epo availability rather than Epo concentration (Villafuerte et al., 2014). The ratio of

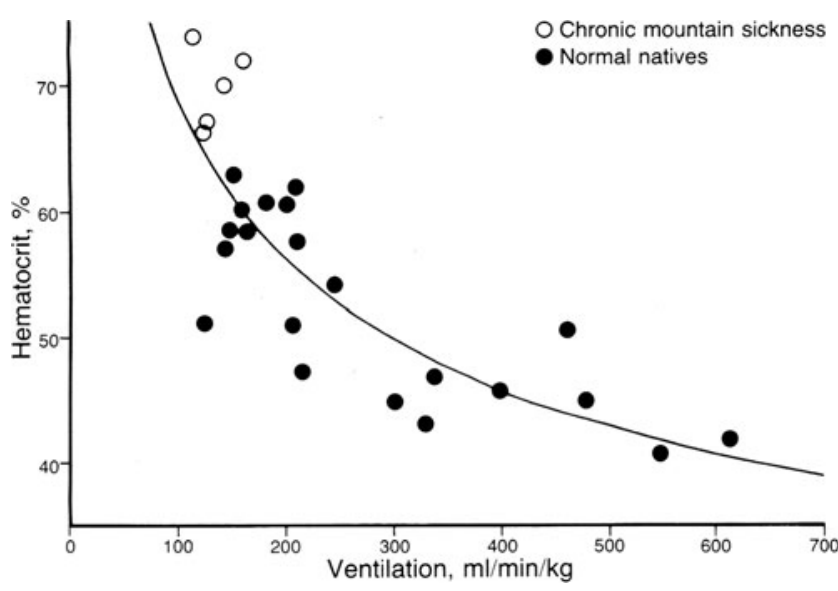

FIG. 2. Relationship between hematocrit and pulmonary ventilation in native Andean healthy highlanders $(\boldsymbol{O})$ and CMS patients $(O)$ at $4500 \mathrm{~m}$. The figure shows the inverse relationship between these two variables using individual data points. Reproduced from Winslow and Monge (1987). 
serum Epo to its soluble receptor (sEpoR), an endogenous antagonist of Epo action, represents an index of circulating Epo availability. Lower sEpoR levels and higher Epo-tosEpoR ratios show good correlation with $\mathrm{Hb}$ during daytime and nighttime (Villafuerte et al., 2014, 2016). Also recently, the lack of correlation of circulating Epo with $\mathrm{Hb}$ concentration in CMS has been explained in terms of an increase in local Epo production in the bone marrow, without an increase in plasma Epo concentration ( $\mathrm{Su}$ et al., 2015).

The significant variability in the apparent causes of EE and CMS suggests that the origin of the condition involves multiple levels. Some patients develop severe hypoxemia due to evident depressed ventilation during day or night and trigger excessive erythrocyte production. Some patients, on the other hand, develop EE with moderate hypoxemia but increased plasma Epo availability or local Epo production. Evidence at different levels suggests a genetic basis for EE and CMS. Recently, a single-nucleotide polymorphism in the SENP1 gene, which encodes a protease that regulates erythropoiesis, was found to be linked to EE (Zhou et al., 2013; Cole et al., 2014; Hsieh et al., 2016). Furthermore, this association is supported by functional studies at the cellular level where fibroblasts obtained from CMS patients express less SENP1 protein than their healthy counterparts when exposed to hypoxia (Zhou et al., 2013). This is an important observation since physiologically a lower expression of this gene supposes an enhanced erythropoietic activity. Also recently, a polymorphic variant of the $V E G F-A$ gene was reported to be associated with CMS (Espinoza et al., 2014), indicating a possible genetic basis for vascular differences between CMS patients and healthy highlanders. These are still very early but encouraging findings in the linkage of specific genes to the presence and development of EE and CMS. There is, however, the need to explore further specific gene associations that may explain the observed multi-level differences such as those in the control of ventilation, hypoxic reactivity of pulmonary artery pressure, vascular control, and the distinct steps of erythropoiesis and metabolism.

\section{Risk Factors}

History of CMS, history of lack of respiratory sensitivity to hypoxia and hypoventilation, sleep apnea and all hypopneas, accentuated hypoxemia, advanced age, male gender, postmenopausal state, and overweight are all risk factors for CMS (Wu et al., 1998; Leon-Velarde et al., 2005).

Given the relevance of inherited traits in the physiological adaptation to high altitude, CMS is more likely to occur in individuals with a family history of the condition, and with a reduced respiratory response to hypoxic stimulus. In the absence of other health complications, CMS prevalence within a particular population varies considerably between gender and age ranges. A higher prevalence is observed in men than in women, and in postmenopausal women compared with premenopausal women (Leon-Velarde et al., 1997; Wu et al., 1998; Leon-Velarde et al., 2001). Possibly, premenopausal women present a protection against the development of EE given by an effect of female hormones on ventilation, and by menstruation acting as regular natural phlebotomies (Moore, 2000). Increasing prevalence of CMS can also be observed with advancing age (Monge et al., 1989; De Ferrari et al., 2014). In Cerro de Pasco, Perú, the prevalence of CMS among young adults (20-29 years) is around $7 \%$ but it can reach $33 \%$ in elders (>60 years). The effect of age on hematocrit could be associated with a natural age-dependent reduction in ventilation and the consequent accentuation of arterial hypoxemia (Sime et al., 1975). Nocturnal hypoxemia has also been suggested as a potential risk factor for the development of CMS. Patients suffering from the syndrome spend a higher percentage of sleep time with oxygen saturation below $80 \%$ when compared with healthy highlanders (Kryger et al., 1978a; Spicuzza et al., 2004). However, there is still controversy over whether this accentuated hypoxemia is related to sleep-disordered breathing (Kryger et al., 1978a; Sun et al., 1996; Spicuzza et al., 2004). Finally, there is a higher prevalence of the syndrome among those with overweight and obesity (BMI $>25 \mathrm{~kg} / \mathrm{m}^{2}$ ) (Leon-Velarde and Arregui, 1994; De Ferrari et al., 2014).

\section{Management and Treatment}

\section{Nonpharmacological reduction of EE}

The clinical manifestations of CMS gradually disappear after descending to lower altitudes or sea level, and they reappear after returning to a high altitude. Although this practice is very effective in managing the condition, it represents a temporary solution unless the patient moves permanently to a lower-altitude location. Evidence from clinical practice indicates that periodic travel to lower altitudes prevents $\mathrm{Hb}$ values from reaching excessive levels. In severe cases, however, and although impractical for social, family, and economic reasons, the patients should move permanently to a lower altitude. Phlebotomy is another frequent practice that is used to reduce red blood cell mass and $\mathrm{Hb}$ concentration, at least close to values considered normal for the altitude of residence. Although no randomized controlled trials on the safety and efficacy of this therapy have been carried out, several studies show that phlebotomy with or without isovolemic hemodilution reduces hematocrit, improves oxygenation, and leads to relief of symptomatology (Cruz et al., 1979; Wu, 1979; Klein, 1983; Winslow et al., 1985). There are, however, two key concerns regarding this practice related to iron deficiency and a rebound effect on $\mathrm{Hb}$ concentration. Smith et al. (2009) showed that decreasing hematocrit from $73 \%$ to $59 \%$ in CMS patients at $4340 \mathrm{~m}$ caused iron deficiency, which increases pulmonary artery pressure and may aggravate pulmonary hypertension. The second concern arises from the common observation in clinical practice that if the patient stays at a high altitude, hematocrit usually reaches and exceeds pretreatment values within a few weeks with a recurrence of symptoms. Therefore, in the long term, counterproductive effects on hematocrit may result in an aggravated CMS condition. Unfortunately, there are no systematic reports with follow-up on quantitative measurements and symptomatology after different extents of phlebotomy. It is believed that isovolemic hemodilution is safer than phlebotomy without volume replacement and that it allows a longer lasting improvement of symptoms. Due to its transient effects, invasive nature, and potential counterproductive effects, phlebotomy results in an impractical long-term treatment for EE and CMS.

Physical exercise has been proposed as a more practical noninvasive, nonpharmacological alternative treatment. Evidence suggests that aerobic exercise might play a beneficial role in decreasing the erythrocytic mass and in reducing CMS symptomatology. Cornolo et al. (2005) showed that Hb con- 
centration in native high-altitude athletes is similar to sea-level values, and significantly lower than $\mathrm{Hb}$ values observed in nonathlete healthy highlanders at the same altitude. However, physical exercise in CMS patients has to be performed with care due to the development of severe pulmonary hypertension (Stuber et al., 2010; Pratali et al., 2012). Evidence from clinical practice supports the positive effect of exercise on hematocrit and CMS symptomatology in patients who started a regular mild exercise regime. It is not yet clear, however, whether the reduction of $\mathrm{Hb}$ concentration is a consequence of improved oxygenation due to training, increased exercise-related hemolysis, or both. Nevertheless, regular exercise training is an interesting nonpharmacological approach in the treatment of $\mathrm{EE}$ and deserves further research.

\section{Pharmacological reduction of EE}

Several pharmacological approaches have shown promising results in the treatment of EE and CMS. Among these, ACE inhibitors (Vargas et al., 1996; Plata et al., 2002), dopaminergic antagonists, and ventilatory stimulants such as me- droxyprogesterone (Kryger et al., 1978b) and almitrine (Villena et al., 1985) have been assessed for the treatment of EE in CMS (Table 4). However, few studies show clinical evidence for safety and efficacy in CMS treatment. In this review, we focus on the treatment of EE with acetazolamide, a systemic sulphonamide inhibitor of carbonic anhydrase, as it has the most recent and longer-term randomized controlled trials with clinical significance in the treatment of CMS.

Two randomized, double-blind, placebo-controlled studies assessed the efficacy and safety of acetazolamide treatment in CMS patients in Cerro de Pasco. Results showed that acetazolamide ( $250 \mathrm{mg} /$ day) decreased hematocrit, serum Epo, and serum transferrin; and it increased $\mathrm{PaO}_{2}$ and serum ferritin. Also, acetazolamide increased nocturnal $\mathrm{SpO}_{2}$ and reduced the number of apnea-hypopnea episodes and pulmonary vascular resistance. The decrease in Epo was attributed mainly to the acetazolamide-induced increase in ventilation and $\mathrm{SpO}_{2}$ (Richalet et al., 2005, 2008).

Overall, acetazolamide reduces hypoventilation and blunts erythropoiesis. Also, it improves pulmonary circulation without adverse effects. Its implementation as a chronic

Table 4. Pharmacological Approaches for the Treatment of CMS

\begin{tabular}{|c|c|c|c|c|c|c|}
\hline $\begin{array}{l}\text { Pharmacological } \\
\text { agent }\end{array}$ & Dose & $\begin{array}{c}\text { Number } \\
\text { of CMS } \\
\text { participants }\end{array}$ & Duration & Altitude & Outcome & Reference \\
\hline Enalapril & $10 \mathrm{mg} /$ day & 10: $7 \mathrm{~m}-3 \mathrm{f}$ & 30 days & $4300 \mathrm{~m}$ & $\begin{array}{l}\text { Hct decreased from } 66 \% \text { to } \\
64 \% \text { after } 2 \text { weeks of } \\
\text { treatment and remained } \\
\text { stable for the following } \\
2 \text { weeks. Improvement } \\
\text { in signs and symptoms. }\end{array}$ & $\begin{array}{l}\text { Vargas et al. } \\
\text { (1996) }\end{array}$ \\
\hline Enalapril & $5 \mathrm{mg} /$ day & 13: $11 \mathrm{~m}-2 \mathrm{f}$ & 2 years & $3600 \mathrm{~m}$ & $\begin{array}{l}\text { Reduction in } \mathrm{Hb}(2.4 \mathrm{~g} / \mathrm{dL} \\
\text { after } 1 \text { year and } 4.3 \mathrm{~g} / \mathrm{dL} \\
\text { after } 2 \text { years }), \mathrm{Hct}(3.9 \% \\
\text { after } 1 \text { year and } 6.7 \% \\
\text { after } 2 \text { years }), \text { and } \\
\text { proteinuria }(74.1 \mathrm{mg} / \\
24 \mathrm{~h} \text { after } 1 \text { year and } \\
110.9 \mathrm{mg} / 24 \mathrm{~h} \text { after } \\
2 \text { years }) .\end{array}$ & $\begin{array}{l}\text { Plata et al. } \\
\qquad(2002)\end{array}$ \\
\hline $\begin{array}{l}\text { Medroxy- } \\
\text { progesterone }\end{array}$ & $20 \mathrm{mg} / 3$ times per day & $17 \mathrm{~m}$ & 10 weeks & $3100 \mathrm{~m}$ & $\begin{array}{l}\mathrm{SpO}_{2} \text { increased from } \\
83.9 \% \text { to } 89.6 \% \text {, and } \\
\text { Hct decreased from } \\
60.1 \% \text { to } 52.1 \% \text {. } \\
\text { Improvement in signs } \\
\text { and symptoms. }\end{array}$ & $\begin{array}{l}\text { Kryger et al. } \\
\text { (1978) }\end{array}$ \\
\hline Almitrine & $1.5 \mathrm{mg} / \mathrm{kg} /$ day & 12 & 4 weeks & $3600 \mathrm{~m}$ & Hct decreased by $3.5 \%$. & $\begin{array}{l}\text { Villena et al. } \\
(1985)\end{array}$ \\
\hline Acetazolamide & $250 \mathrm{mg} /$ day & $9 \mathrm{~m}$ & 3 weeks & $4300 \mathrm{~m}$ & $\begin{array}{l}\text { Hct decreased by } 7.1 \% \text {; } \\
\text { Epo, by } 67 \% ; \text { and } \\
\mathrm{P}_{\text {ETCO2 }}, \text { by } 14.2 \% \text {. } \\
\text { Nocturnal } \mathrm{SpO}_{2} \text { and } \\
\mathrm{P}_{\text {ETO2 }} \text { increased by } \\
4.3 \% \text { and } 6.5 \%, \\
\text { respectively. } \\
\text { Improvement in signs } \\
\text { and symptoms. }\end{array}$ & $\begin{array}{l}\text { Richalet et al. } \\
\text { (2005) }\end{array}$ \\
\hline Acetazolamide & $250 \mathrm{mg} /$ day & $34 \mathrm{~m}$ & 12 weeks & $4300 \mathrm{~m}$ & $\begin{array}{l}\text { Hct decreased from } 69 \% \\
\text { to } 64 \% \text {, and } \mathrm{SpO}_{2} \\
\text { increased from } 82 \% \text { to } \\
84 \% \text {. Improvement in } \\
\text { signs and symptoms. }\end{array}$ & $\begin{array}{l}\text { Richalet et al. } \\
\text { (2008) }\end{array}$ \\
\hline
\end{tabular}

\footnotetext{
m, male; f, female; $\mathrm{P}_{\mathrm{ETO} 2}$, end-tidal $\mathrm{PO}_{2} ; \mathrm{P}_{\mathrm{ETCO} 2}, \mathrm{PCO}_{2}$.
} 
treatment for this disease appears efficient and safe. Longer trials would be advisable to assess potential long-term consequences of the chronic inhibition of carbonic anhydrase in the different organs and systems.

\section{Recommendations}

Given the progressive and incapacitating nature of CMS, periodic check-ups $(\sim 1$ year $)$ on $\mathrm{Hb}$ concentration or hematocrit, and associated comorbidities are necessary. Also, periodic travel to lower altitudes is recommended for those close to or with diagnosed EE. Heavy exercise should be avoided, and mild/moderate exercise should be performed only under a supervised controlled regime. Treatment with acetazolamide $(250 \mathrm{mg} /$ day $)$ is safe up to 6 months. Severe cases should move permanently to a lower altitude or sea level.

\section{Acknowledgments}

F.C.V. is supported by a Wellcome Trust Public Health and Tropical Medicine Intermediate Fellowship. The authors would like to thank Cecilia Anza-Ramirez for assistance in preparing this article.

\section{Author Disclosure Statement}

No competing financial interests exist.

\section{References}

Arias-Stella J. (1971). Chronic mountain sickness: Pathology and definition. In: High Alltitude Physiology: Cardiac and Respiratory Aspects. R Porter and J Knight, eds. Churchill Livingstone, Edinburgh and London. pp. 31-40.

Bailey DM, Rimoldi SF, Rexhaj E, Pratali L, Salinas Salmon C, Villena M, McEneny J, Young IS, Nicod P, Allemann Y, Scherrer U, and Sartori C. (2013). Oxidative-nitrosative stress and systemic vascular function in highlanders with and without exaggerated hypoxemia. Chest 143:444-451.

Chinese High Altitude Medical Association. (1996). Recommendation for the classification and diagnostic criteria of high altitude disease in China. Chin J High Alt Med 6:2-4.

Claydon VE, Norcliffe LJ, Moore JP, Rivera-Ch M, LeonVelarde F, Appenzeller O, and Hainsworth R. (2004). Orthostatic tolerance and blood volumes in Andean high altitude dwellers. Exp Physiol 89:565-571.

Cole AM, Petousi N, Cavalleri GL, and Robbins PA. (2014).Genetic variation in SENP1 and ANP32D as predictors of chronic mountain sickness. High Alt Med Biol 15: 497-499.

Cornolo J, Brugniaux JV, Macarlupu JL, Privat C, LeonVelarde F, and Richalet JP. (2005). Autonomic adaptations in andean trained participants to a 4220-m altitude marathon. Med Sci Sports Exerc 37:2148-2153.

Cruz JC, Diaz C, Marticorena E, and Hilario V. (1979). Phlebotomy improves pulmonary gas exchange in chronic mountain polycythemia. Respiration 38:305-313.

De Ferrari A, Miranda J, and Gilman R. (2014). Prevalence, clinical profile, iron status, and subject-specific traits for excessive erythrocytosis in Andean adults living permanently at 3825 meters above sea level. Chest 146:1327-1336.

Espinoza JR, Alvarez G, Leon-Velarde F, Preciado HF, Macarlupu JL, Rivera-Ch M, Rodriguez J, Favier J, GimenezRoqueplo AP, and Richalet JP. (2014). Vascular endothelial growth factor-A is associated with chronic mountain sickness in the Andean population. High Alt Med Biol 15:146-154.
Gonzales GF, and Tapia V. (2013). [Association of high altitude-induced hypoxemia to lipid profile and glycemia in men and women living at $4,100 \mathrm{~m}$ in the Peruvian Central Andes]. Endocrinol Nutr. 60:79-86.

Groepenhoff H, Overbeek MJ, Mule M, van der Plas M, Argiento P, Villafuerte FC, Beloka S, Faoro V, Macarlupu JL, Guenard H, de Bisschop C, Martinot JB, Vanderpool R, Penaloza D, and Naeije R. (2012). Exercise pathophysiology in patients with chronic mountain sickness exercise in chronic mountain sickness. Chest 142:877-884.

Hsieh MM, Callacondo D, Rojas-Camayo J, Quesada-Olarte J, Wang X, Uchida N, Maric I, Remaley AT, Leon-Velarde F, Villafuerte FC, and Tisdale JF. (2016). SENP1 but not fetal hemoglobin differentiates chronic mountain sickness from healthy Andean highlanders. Exp Hematol pii: S0301472X(16)30001-30007. Doi: 10.1016/j.exphem.2016.02.010.

Hurtado A. (1942). Chronic mountain sickness. JAMA 120: 1278-1283.

Jefferson JA, Escudero E, Hurtado ME, Kelly JP, Swenson ER, Wener MH, Burnier M, Maillard M, Schreiner GF, Schoene RB, Hurtado A, and Johnson RJ. (2002). Hyperuricemia, hypertension, and proteinuria associated with high-altitude polycythemia. Am J Kidney Dis 39:1135-1142.

Klein H. (1983). Isovolemic hemodilution in high-altitude polycythemia. Proceedings of the International Symposium on Acclimatization, Adaptation, and Tolerance to High Altitude, US Department of Health and Human Services.

Kryger M, Glas R, Jackson D, McCullough RE, Scoggin C, Grover RF, and Weil JV. (1978a). Impaired oxygenation during sleep in excessive polycythemia of high altitude: Improvement with respiratory stimulation. Sleep 1:3-17.

Kryger M, McCullough RE, Collins D, Scoggin CH, Weil JV, and Grover RF. (1978b). Treatment of excessive polycythemia of high altitude with respiratory stimulant drugs. Am Rev Respir Dis 117:455-464.

Leon-Velarde F, and Arregui A. (1994). Desadaptacion a la vida en las grandes alturas. In: Travaux de l'Institut Francaise d'Etudes Andines, Volume 85. F Leon-Velarde and A Arregui, eds. Institut Français d'études Andines (IFEA), Lima.

Leon-Velarde F, Arregui A, Vargas M, Huicho L, Acosta R. (1994). Chronic mountain sickness and chronic lower respiratory tract disorders. Chest 106:151-155.

Leon-Velarde F, Maggiorini M, Reeves JT, Aldashev A, Asmus I, Bernardi L, Ge RL, Hackett P, Kobayashi T, Moore LG, Penaloza D, Richalet JP, Roach R, Wu T, Vargas E, Zubieta-Castillo G, and Zubieta-Calleja G. (2005). Consensus statement on chronic and subacute high altitude diseases. High Alt Med Biol 6:147-157.

Leon-Velarde F, Ramos MA, Hernandez JA, De Idiaquez D, Munoz LS, Gaffo A, Cordova S, Durand D, and Monge C. (1997). The role of menopause in the development of chronic mountain sickness. Am J Physiol 272(1 Pt 2):R90-4.

Leon-Velarde F, and Richalet JP. (2006). Respiratory control in residents at high altitude: Physiology and pathophysiology. High Alt Med Biol 7:125-137.

Leon-Velarde F, Rivera-Ch M, Huicho L, and Villafuerte FC. (2014). Chronic mountain sickness. In: High Altitude.Human Adaptation to Hypoxia. ER Swenson and P Bartsch, eds. Springer, New York. p. 429.

Leon-Velarde F, Rivera-Chira M, Tapia R, Huicho L, and Monge CC. (2001). Relationship of ovarian hormones to hypoxemia in women residents of $4,300 \mathrm{~m}$. Am J Physiol Regul Integr Comp Physiol 280:R488-R493.

Maignan M, Rivera-Ch M, Privat C, Leon-Velarde F. Richalet JP, and Pham I. (2009). Pulmonary pressure and cardiac function in chronic mountain sickness patients. Chest 135:499-504. 
Monge C. (1942). Life in the Andes and chronic mountain sickness. Science 95:79-84.

Monge C. (1943). Chronic mountain sickness. Physiol Rev 23:166-184.

Monge C, Leon-Velarde F, and Arregui A. (1989). Increasing prevalence of excessive erythrocytosis with age among healthy high-altitude miners. N Engl J Med 321:1271.

Monge-C C, Arregui A, and Leon-Velarde F. (1992). Pathophysiology and epidemiology of chronic mountain sickness. Int J Sports Med 13(Suppl 1):S79-S81.

Moore LG. (2000). Comparative human ventilatory adaptation to high altitude. Respir Physiol 121:257-276.

Moore LG. (2001). Human genetic adaptation to high altitude.High Alt Med Biol 2:257-279.

Okumiya K, Sakamoto R, Fukutomi E, Kimura Y, Ishimoto Y, Chen WL, Ishikawa M, Hozo R, Otsuka K, Matsubayashi K, Wada T, Inamura T, Lazo M, Lu JP, and Garcia PJ. (2011). Strong association between polycythemia and glucose intolerance in older adults living at high altitudes in the Andes. J Am Geriatr Soc 59:1971-1973.

Okumiya K, Sakamoto R, Kimura Y, Ishimoto Y, Wada T, Ishine M, Ishikawa M, Nakajima S, Hozo R, Ge R. L, Norboo T, Otsuka K, and Matsubayashi K. (2010). Strong association between polycythemia and glucose intolerance in elderly high-altitude dwellers in Asia. J Am Geriatr Soc 58:609-611.

Pei T, Li X, Tao F, Xu H, You H, Zhou L, Liu Y, and Gao Y. (2012). Burden of disease resulting from chronic mountain sickness among young Chinese male immigrants in Tibet. BMC Public Health 12:401.

Peñaloza D, and Arias-Stella J. (2007). The heart and pulmonary circulation at high altitudes: healthy highlanders and chronic mountain sickness. Circulation 115:1132-1146.

Peñaloza D, Sime F, and Ruiz L. (1971). Corpulmonale in chronic mountain sickness: Present concept of Monge's disease. In: High Altitude Physiology: Cardiac and Respiratory Aspects. R Porter and J Knight, eds. Churchill Livingstone, Edinburgh. pp. 41-60.

Plata R, Cornejo A, Arratia C, Anabaya A, Perna A, Dimitrov BD, Remuzzi G,. and Ruggenenti P. (2002). Angiotensin-convertingenzyme inhibition therapy in altitude polycythaemia: A prospective randomised trial. Lancet 359:663-666.

Pratali L, Rimoldi SF, Rexhaj E, Hutter D, Faita F, Salmon CS, Villena M, Sicari R, Picano E, Allemann Y, Scherrer U, and Sartori C. (2012). Exercise induces rapid interstitial lung water accumulation in patients with chronic mountain sickness. Chest 141:953-958.

Richalet JP, Rivera-Ch M, Maignan M, Privat C, Pham I, Macarlupu JL, Petitjean O, and Leon-Velarde F. (2008). Acetazolamide for Monge's disease: Efficiency and tolerance of 6-month treatment. Am J Respir Crit Care Med 177:1370-1376.

Richalet JP, Rivera M, Bouchet P, Chirinos E, Onnen I, Petitjean O, Bienvenu A, Lasne F, Moutereau S, and Leon-Velarde F. (2005). Acetazolamide: A treatment for chronic mountain sickness. Am J Respir Crit Care Med 172:1427-1433.

Rimoldi SF, Rexhaj E, Pratali L, Bailey DM, Hutter D, Faita F, Salmon CS, Villena M, Nicod P, Allemann Y, Scherrer U, and Sartori C. (2012). Systemic vascular dysfunction in patients with chronic mountain sickness. Chest 141:139-146.

Sahota IS, and Panwar NS. (2013).Prevalence of chronic mountain sickness in high altitude districts of Himachal Pradesh. Indian J Occup Environ Med 17:94-100.

Sherpa LY, Deji, Stigum H, Chongsuvivatwong V, Luobu O, Thelle DS, Nafstad P, and Bjertness E. (2011). Lipid profile and its association with risk factors for coronary heart dis- ease in the highlanders of Lhasa, Tibet. High Alt Med Biol 12:57-63.

Sime F, Monge C, and Whittembury J. (1975). Age as a cause of chronic mountain sickness (Monge's disease). Int J Biometeorol 19:93-98.

Smith TG, Talbot NP, Privat C, Rivera-Ch M, Nickol AH, Ratcliffe PJ, Dorrington KL, Leon-Velarde F, and Robbins PA. (2009). Effects of iron supplementation and depletion on hypoxic pulmonary hypertension: Two randomized controlled trials. JAMA 302:1444-1450.

Spicuzza L, Casiraghi N, Gamboa A, Keyl C, Schneider A, Mori A, Leon-Velarde F, Di Maria GU, and Bernardi L. (2004). Sleep-related hypoxaemia and excessive erythrocytosis in Andean high-altitude natives. Eur Respir J 23:41-46.

Spielvogel H, Vargas E, Paz Zamora M, Haas J, Beard J, Tufts DG, and Cudkowicz L. (1981). Poliglobulia y Ejercicio Muscular. Gaceta del Torax XIII (48):4-6-11.

Stocker R, and Keaney JF, Jr. (2004). Role of oxidative modifications in atherosclerosis. Physiol Rev 84:1381-1478.

Stuber T, Sartori C, Schwab M, Jayet PY, Rimoldi SF, Garcin S, Thalmann S, Spielvogel H, Salmon CS, Villena M, Scherrer U, and Allemann Y. (2010). Exaggerated pulmonary hypertension during mild exercise in chronic mountain sickness. Chest 137:388-392.

Su J, Li Z, Cui S, Ji L, Geng H, Chai K, Ma X, Bai Z, Yang Y, Wuren T, Ge RL, and Rondina MT. (2015). The local HIF2alpha/EPO pathway in the bone marrow is associated with excessive erythrocytosis and the increase in bone marrow microvessel density in chronic mountain sickness. High Alt Med Biol 16:318-330.

Sun S, Oliver-Pickett C, Ping Y, Micco AJ, Droma T, Zamudio S, Zhuang J, Huang SY, McCullough RG, Cymerman A, and Moore LG. (1996). Breathing and brain blood flow during sleep in patients with chronic mountain sickness. J Appl Physiol (1985) 81:611-618.

Vargas M, Leon-Velarde F, Monge CC, Orozco E, and Rey L. (1996). Enalapril in the treatment of chronic mountain sickness. Wilderness Environ Med 7:193-194.

Villafuerte FC, Corante N, Anza-Ramírez C, Figueroa-Mujíca R, Vizcardo-Galindo G, Mercado A, Macarlupú JL, and León-Velarde F. (2016). Plasma soluble erythropoietin receptor is decreased during sleep in Andean highlanders with chronic mountain sickness. J Appl Physiol (1985) [Epub ahead of print]; DOI: 10.1152/japplphysiol.00107.2016.

Villafuerte FC, Macarlupu JL, Anza-Ramirez C, CorralesMelgar D, Vizcardo-Galindo G, Corante N, and LeonVelarde F. (2014). Decreased plasma soluble erythropoietin receptor in high-altitude excessive erythrocytosis and chronic mountain sickness. J Appl Physiol (1985) 117:1356-1362.

Villena M, Vargas E, Guenard H, Nallar N, Tellez W, and Spielvogel H. (1985). [Double-blind study on the action of almitrine in patients with polycythemia of high altitude]. Bull Eur Physiopathol Respir 21:165-170.

Winslow R, and Monge-C C. (1987). Hypoxia, Polycythemia, and Chronic Mountain Sickness. Johns Hopkins University Press, Baltimore, MD.

Winslow RM, Monge CC, Brown EG, Klein HG, Sarnquist F, Winslow NJ, and McKneally SS. (1985). Effects of hemodilution on $\mathrm{O} 2$ transport in high-altitude polycythemia. J Appl Physiol 59:1495-1502.

Wu T. (1979). Excessive polycythemia of high altitude: An analysis of 82 cases [in Chinese]. Chin J Hematol 3:27-32.

Wu TY, Li W, Li Y, Ge RL, Cheng Q, Wang Z, Zhao G, Wei L, Jin Y, and Don G. (1998). Epidemiology of chronic mountain sickness: Ten years study in Quingai -Tibet. In: Progress in 
Mountain Medicine and High Altitude Physiology. H Ohno, K Kobayashi, S Masuyama, M Nakashima and M Matsumoto, eds. Press Committee of the Third World Congress, Japan, 1998, pp. 120-125.

Zhou D, Udpa N, Ronen R, Stobdan T, Liang J, Appenzeller O, Zhao HW, Yin Y, Du Y, Guo L, Cao R, Wang Y, Jin X, Huang C, Jia W, Cao D, Guo G, Gamboa JL, Villafuerte F, Callacondo D, Xue J, Liu S, Frazer KA, Li Y, Bafna V, and Haddad GG. (2013). Whole-genome sequencing uncovers the genetic basis of chronic mountain sickness in Andean highlanders. Am J Hum Genet 93:452-462.
Address correspondence to: Francisco C. Villafuerte, DPhil Laboratorio de Fisiología Comparada Departamento de Ciencias Biológicas y Fisiológicas Facultad de Ciencias y Filosofía Universidad Peruana Cayetano Heredia Av. Honorio Delgado 430 Lima 31 Peru

E-mail: francisco.villafuerte@upch.pe 